Jurnal Indonesia Sosial Teknologi: p-ISSN: 2723 - 6609

e-ISSN: 2548-1398

Vol. 1, No. 4 November 2020

\title{
MODEL OPTIMALISASI PELAKSANAAN PROGRAM PERCEPATAN PEMBANGUNAN DESA/KELURAHAN (P2DK) DI KABUPATEN SAROLANGUN
}

\author{
Rahmat Suharto \\ Politeknik STIA LAN Bandung, Jawa Barat, Indonesia \\ Email : rahmatsuharto23@gmail.com
}

\begin{abstract}
Through Regional Regulation No. 5 of 2014, the Government of Sarolangun District Government issued a policy on the Program for the Acceleration of Rural/ Urban Development Program (P2DK), this program is expected to improve welfare and reduce poverty with the assistance of funds worth two hundred million rupiah for each village and village with various economic empowerment menus which is offered. However, based on the phenomenon of the issue problem, it shows that the poverty level of Sarolangun Regency is still in the fifth position poorest districts in Jambi Province. The purpose of this study was to analyze the implementation of the P2DK Program policy at the Sarolangun District Community and Village Empowerment Service (PMD). The method used is a qualitative method with a case study approach with a focus on problems to find out and analyze any obstacles experienced in implementation by using the Edward III policy implementation model that puts forward four factors, namely: Communication, Resources, Attitudes / Dispositions, and Bureaucratic Structure. The results of this study indicate that the implementation of the P2DK Program in the Sarolangun District Village and Community Empowerment Office was still encountered by several obstacles including the lack of information received by the community, lack of resources to assist the community during carrying out activities, the implementation of the P2DK Program was still carried out by a single actor, not involving the agency technically related. Suggestions from this research are to design an institutional development model to collaborate with technical agencies to improve communication with the community, and reward and punishment system approaches.
\end{abstract}

Keywords: Policy Implementation, Program Optimization Model, Local Government Policy

\begin{abstract}
Abstrak
Melalui Peraturan Daerah Nomor 5 Tahun 2014 Pemerintah Kabupaten Sarolangun menerbitkan kebijakan Program Percepatan Pembangunan Desa/Kelurahan (P2DK), Program ini diharapkan dapat meningkatkan kesejahteraan dan mengurangi angka kemiskinan dengan bantuan dana senilai dua ratus juta rupiah untuk setiap desa dan kelurahan dengan berbagai menu pemberdayaan ekonomi yang ditawarkan. Namun berdasarkan fenomena masalah menunjukkan bahwa tingkat kemiskinan Kabupaten Sarolangun masih berada pada urutan lima besar kabupaten termiskin dalam Provinsi
\end{abstract}


Jambi. Tujuan dari penelitian ini adalah menganalisis implementasi kebijakan Program P2DK pada Dinas Pemberdayaan Masyarakat dan Desa (PMD) Kabupaten Sarolangun. Metode yang digunakan yaitu metode kualitatif dengan pendekatan studi kasus dengan fokus masalah untuk mengetahui dan menganalisis hambatan apa saja yang dialami dalam pelaksanaan dengan menggunakan model implementasi kebijakan Edward III yang mengedepankan empat faktor, yaitu: Komunikasi, Sumber Daya, Sikap/Disposisi, dan Struktur Birokrasi. Hasil penelitian ini menunjukkan bahwa implementasi Program P2DK di Dinas PMD Kabupaten Sarolangun masih ditemui beberapa kendala diantaranya yaitu masih kurangnya informasi yang diterima oleh masyarakat, kurangnya sumber daya untuk mendampingi masyarakat selama melaksanakan kegiatan, pelaksanaan Program P2DK masih di lakukan oleh single actor saja, belum melibatkan dinas teknis terkait. Saran dari penelitian ini yakni merancang model pengembangan kelembagaan untuk bekerjasama dengan dinas teknis untuk meningkatkan komunikasi dengan masyarakat, dan pendekatan sistem reward dan punishment.

Kata kunci: Implementasi Kebijakan, Model Optimalisasi Program, Kebijakan Pemerintah Daerah

\section{Pendahuluan}

Dalam upaya mendukung tercapainya lima visi Indonesia Maju 2019-2024 periode kedua pemerintahan Presiden Joko Widodo, dimana kelima visi ini diharapkan mendorong Indonesia lebih produktif, berdaya saing, dan fleksibilitas dalam menghadapi tantangan global yang dinamis dan penuh resiko, diantaranya yaitu Anggaran Pendapatan Belanja Negara (APBN) dipastikan harus memiliki manfaat ekonomi dan meningkatkan kesejahteraan rakyat, sebagai lanjutan dari sembilan agenda strategis (NAWACITA) yang menjadi program prioritas Presiden Republik Indonesia pada tahun 2014-2019 di dalam poin ketiga disebutkan yaitu membangun Indonesia dari pinggiran dengan memperkuat daerah-daerah dan desa dalam kerangka negara kesatuan.

Sebagaimana diamanatkan Undang-Undang Nomor 6 Tahun 2014 tentang Desa Pasal 78 ayat (1) Pembangunan Desa bertujuan meningkatkan kesejahteraan masyarakat Desa dan kualitas hidup manusia serta penanggulangan kemiskinan melalui pemenuhan kebutuhan dasar, pembangunan sarana dan prasarana desa, pengembangan potensi ekonomi lokal, serta pemanfaatan sumber daya alam dan lingkungan secara berkelanjutan. Pasal 81 ayat (5) Pelaksanaan program sektoral yang masuk ke desa di informasikan kepada Pemerintah Desa untuk diintegrasikan dengan pembangunan desa. Pasal 83 ayat (2) Pembangunan Kawasan Perdesaan dilaksanakan dalam upaya mempercepat dan meningkatkan kualitas pelayanan, pembangunan, dan pemberdayaan masyarakat Desa di Kawasan Perdesaan melalui pendekatan pembangunan partisipatif.

Sejalan dengan diberlakukannya otonomi daerah sebagaimana tertuang dalam Undang-Undang Nomor 23 Tahun 2014 tentang Pemerintahan Daerah yang memberikan kewenangan bagi pemerintah daerah untuk menyusun kebijakan, maka peran pejabat publik di daerah dalam melakukan inovasi kebijakan publik akan semakin meningkat dan memberikan dampak yang positif bagi kualitas kebijakan atau peraturan yang akan disusun dan telah dihasilkan. Konsep otonomi yang dimaksudkan disini adalah 
kewenangan daerah otonom untuk mengatur dan mengurus sendiri urusan pemerintahan dan kepentingan masyarakat setempat sesuai dengan peraturan perundangan yang berlaku. Hakekat keberadaan pemerintahan dan birokrasi itu adalah dalam rangka menjalankan tugas memberikan pelayanan sebaik-baiknya kepada masyarakat. Pentingnya pemberdayaan dan peran serta masyarakat dalam penyelenggaraan Pemerintahan Daerah dituangkan dalam dasar pertimbangan huruf b Undang-Undang Nomor 23 Tahun 2014 tentang Pemerintahan Daerah, yang berbunyi Bahwa penyelenggaraan pemerintahan daerah diarahkan untuk mempercepat terwujudnya kesejahteraan masyarakat melalui peningkatan pelayanan, pemberdayaan, dan peran serta masyarakat, serta peningkatan daya saing daerah dengan memperhatikan prinsip demokrasi, pemerataan, keadilan, dan kekhasan suatu daerah dalam sistem Negara Kesatuan Republik Indonesia (Agustino, 2014).

Melalui Bidang Usaha Ekonomi Masyarakat dan Teknologi Tepat Guna (UEM \& TTG) pada Dinas Pemberdayaan Masyarakat dan Desa (PMD), Kabupaten Sarolangun terus mengembangkan suatu strategi inovasi kebijakan percepatan proses dan pemerataan pembangunan desa dan kelurahan sebagai ujung tombak pemerintahan. Hal tersebut merupakan upaya peningkatan kesejahteraan masyarakat sekaligus peningkatan kepercayaan masyarakat kepada pemerintah. Ini menjadi perhatian penting bagi pemerintah sehingga diprioritaskan sebagai arah kebijakan pembangunan. Karena pertumbuhan ekonomi hingga saat ini masih diyakini sebagai indikator penting dalam menilai keberhasilan pembangunan di suatu wilayah/daerah. Deskripsi nilai-nilai produksi dan nilai tambah sektoral berguna pula dalam menentukan arah kebijakan pembangunan dimasa mendatang. Peranan atau kontribusi dari masing-masing sektor dalam PDRB dapat menentukan skala prioritas pembangunan. Tingkat pertumbuhan riil PDRB mencerminkan keberhasilan pembangunan yang sudah dilaksanakan, sedangkan pendapatan per kapita per tahun merupakan indikator tingkat kesejahteraan ekonomi penduduk di suatu daerah (Sarolangun, 2018) .

Struktur perekonomian masyarakat Kabupaten Sarolangun masih didominasi oleh kategori Pertanian, Kehutanan, dan Perikanan. Kategori yang memberikan kontribusi terbesar berikutnya adalah kategori Pertambangan dan Penggalian, dan kategori Konstruksi. Sementara peranan kategori lainnya masih di bawah 10 persen. Hampir 90\% masyarakat Kabupaten Sarolangun hidup dari sektor pertanian dan perkebunan yang terdiri dari 10 Kecamatan dengan 149 Desa dan 9 Kelurahan. Artinya peran sektor pertanian secara umum masih sangat berpengaruh besar dalam perekonomian Kabupaten Sarolangun, dan masih perlu upaya untuk mengembangkan sektor pertanian sebagai yang diunggulkan. potensi berikutnya diikuti sektor pertambangan dan penggalian. Kemudian sektor perdagangan, hotel dan restoran (BPS Provinsi Jambi, 2018).

Inovasi kebijakan publik sebagai sebuah keniscayaan secara prinsip dan substantif akan memberikan penguatan dalam merespon dan menyelesaikan problematika di tengah masyarakat. Strategi inovasi kebijakan Pemerintah Kabupaten Sarolangun dalam menekan angka kemiskinan sudah ada sejak Tahun 2012, yaitu dengan menggulirkan Program Seratus Juta Satu Desa (SERJUSADE) dengan anggaran Rp.100.000.000 
(seratur juta rupiah) yang diatur dalam Peraturan Daerah Nomor 5 Tahun 2013 tentang Program Bantuan Seratus Juta Satu Desa, dengan alokasi dana 70\% pembangunan infrastruktur fisik dan 30\% untuk ekonomi kerakyatan.(Wahab, 2012)

\section{Grafik 1}

Trend Kemiskinan di Kabupaten Sarolangun Tahun 2010-2017

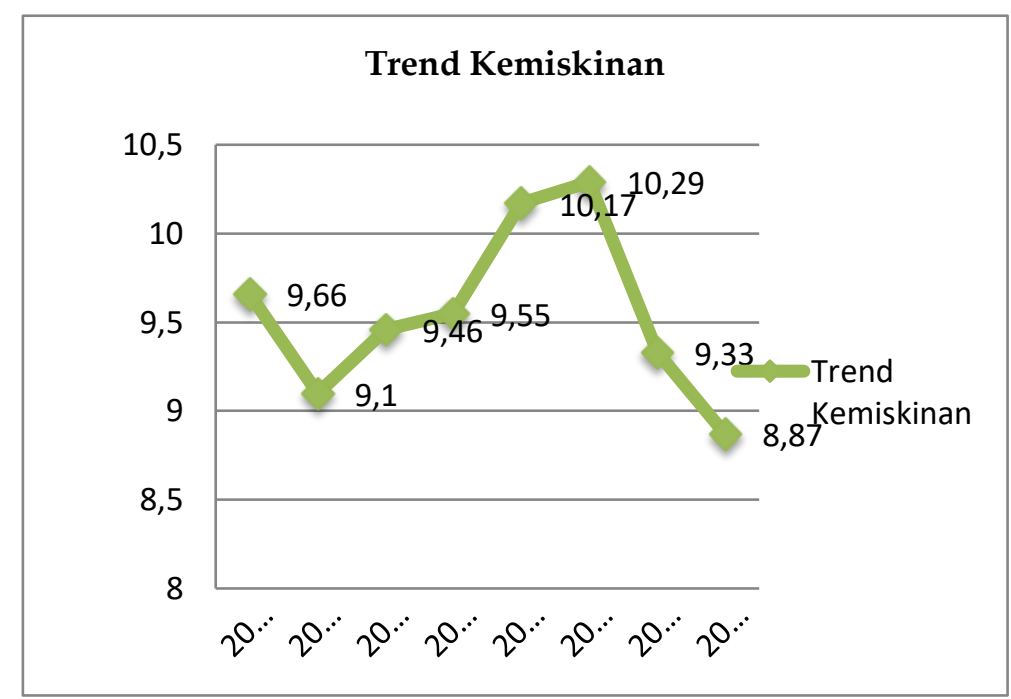

Sumber : BPS Provinsi Jambi 2018

Grafik 1 menunjukkan bahwa inovasi kebijakan program pengentasan kemiskinan yaitu Program SERJUSADE (Seratus Juta Satu Desa) yang dilaksanakan pada tahun 2013 sampai dengan 2014 dengan harapan dapat menekan angka kemiskinan sampai pada tingkat yang serendah-rendahnya dengan memaksimalkan keterlibatan masyarakat secara langsung, namun dalam implementasinya cenderung belum optimal dalam menurunkan angka kemiskinan secara statistik.

Tahun 2014 Program Kebijakan pengentasan kemiskinan di Kabupaten Sarolangun ditingkatkan menjadi Rp.200.000.000 (dua ratus juta rupiah) Satu Desa/Kelurahan, dan berganti nama menjadi Program Percepatan Pembangunan Desa dan Kelurahan (P2DK), yang diatur dalam Peraturan Daerah Nomor 5 Tahun 2014 tentang Program Bantuan Percepatan Pembangunan Desa/Kelurahan, dengan alokasi dana 60\% untuk pembangunan infrastruktur fisik dan $40 \%$ untuk ekonomi kerakyatan. Selanjutnya pada Tahun 2018 Bupati Sarolangun kembali mengevaluasi dan mempertimbangkan Program P2DK, dengan menerbitkan Peraturan Bupati (PERBUP) Nomor 39 Tahun 2018 tentang alokasi dana yang diperuntukkan adalah 100\% pada Bidang Ekonomi Kerakyatan.

Seiring dengan perubahan kebijakan Program SERJUSADE menjadi Program P2DK, angka Kemiskinan di Kabupaten Sarolangun terjadi penurunan pada tahun 20162017. Meskipun demikian posisi Kabupaten Sarolangun di Provinsi Jambi berada pada urutan ke 5 (lima) terbanyak atau hanya berada di atas 4 (empat) kabupaten yang lainnya yaitu Kabupaten Batang Hari, Tanjung Jabung Barat, dan Tanjung Jabung Timur dan 
Merangin. Meskipun trend kemiskinan Kabupaten Sarolangun terjadi penurunan angka kemiskinan, namun secara keseluruhan pada tingkat provinsi masih berada di posisi ke 5 (lima). Untuk itu dibutuhkan upaya untuk mengoptimalisasikan kebijakan dan peran fasilitator, dinamisator, motivator melalui Program P2DK untuk terus menekan angka kemiskinan.

Penelitian ini bertujuan untuk mengevaluasi pelaksanaan kebijakan Program P2DK pada Dinas Pemberdayaan Masyarakat dan Desa (PMD) Kabupaten Sarolangun. Menganalisis hambatan-hambatan dan upaya-upaya dalam pelaksanaan Program P2DK yang sudah dilakukan untuk mengatasi kendala tersebut pada Dinas Pemberdayaan Masyarakat dan Desa Kabupaten Sarolangun, serta menemukan model optimalisasi dalam pelaksanaan kebijakan pengentasan kemiskinan dalam rangka mengoptimalisasikan tujuan dan fungsi Program P2DK pada Dinas Pemberdayaan Masyarakat dan Desa Kebupaten Sarolangun (PMD).

\section{Metode Penelitian}

Penelitian ini dilakukan pada bulan Mei 2019 di Dinas Pemberdayaan Masyarakat dan Desa serta Desa Kertopati dan Desa Mandiangin di Kecamatan Mandiangin kemudian Kelurahan Sungai Benteng di Kecamatan Singkut Kabupaten Sarolangun Provinsi Jambi.

Berdasarkan karakteristik permasalahan atau fenomena yang telah diuraikan dalam penelitian ini, serta mempertimbangkan data yang ada untuk memecahkan masalah sehingga menjadi alasan penulis memilih metode penelitian kualitatif deskriptif dengan pendekatan studi kasus, guna berusaha mencari pemahaman makna berdasarkan fakta yang terjadi di Kabupaten Sarolangun berkaitan dengan pelaksanaan Program Percepatan Pembangunan (Yusria et al., 2019).

Metode penentuan sampling yang digunakan dalam penelitian ini adalah pusposive sampling dengan menentukan informan yang dapat memberikan data dan informasi yang diperlukan dan apabila data tersebut dianggap masih kurang maka peneliti dapat menetapkan informan lainnya dengan pertimbangan informan tersebut akan memberikan data yang lebih lengkap. Teknik dan instrumen pengumpulan data dengan cara wawancara mendalam (in-depth interview), Focus Group Dicussion (FGD) dan kajian dokumentasi terhadap kondisi alamiah dari kondisi lokus dan fokus penelitian (Arifiyanto \& Kurrohman, 2014). Dalam penelitian ini, dokumen yang dikaji adalah dokumen-dokumen yang berkaitan dengan permasalahan pelaksanaan kebijakan Program Percepatan Pembangunan Desa/Kelurahan di Kabupaten Sarolangun.

\section{Hasil dan Pembahasan}

Kebijakan Program Percepatan Pembangunan Desa/Kelurahan (P2DK) sebenarnya merupakan pemberian bantuan keuangan yang diberikan oleh Pemerintah Kabupaten Sarolangun melalui Dinas Pemberdayaan Masyarakat dan Desa (PMD) kepada jajaran pemerintah desa atau kelurahan dengan merujuk kepada Peraturan Daerah Nomor 5 Tahun 2014 tentang Pogram P2DK dan Peraturan Bupati Nomor 39 Tahun 
2018 tentang petunjuk pelaksanaannya. Dana bantuan keuangan berasal dari dana Anggaran Pendapatan dan Belanja Daerah (APBD) Kabupaten Sarolangun yang dialokasikan kepada seluruh pemerintah desa dan kelurahan yang ada dilingkungan Kabupaten Sarolangun.

Tabel 1

Anggaran Program Pengentasan Kemiskinan dari Tahun 2013 s.d 2019

\begin{tabular}{|l|c|c|c|c|}
\hline No & $\begin{array}{c}\text { Nama } \\
\text { Program }\end{array}$ & Tahun & $\begin{array}{c}\text { Per } \\
\text { Desa/Kelurahan }\end{array}$ & $\begin{array}{c}\text { Total } \\
\text { Anggaran }\end{array}$ \\
\hline 1. & SERJUSADE & 2013 & 100.000 .000 & 15.800 .000 .000 \\
\hline 2. & SERJUSADE & 2014 & 100.000 .000 & 15.800 .000 .000 \\
\hline 3. & P2DK & 2015 & 200.000 .000 & 31.600 .000 .000 \\
\hline 4. & P2DK & 2016 & 200.000 .000 & 31.600 .000 .000 \\
\hline 5. & P2DK & 2017 & 200.000 .000 & 31.600 .000 .000 \\
\hline 6. & P2DK & 2018 & 200.000 .000 & 31.600 .000 .000 \\
\hline 7. & P2DK & 2019 & 200.000 .000 & 31.600 .000 .000 \\
\hline
\end{tabular}

Dari tabel 1 diatas diketahui bahwa sejak tahun 2013 pemerintah Kabupaten Sarolangun sudah memberikan bantuan keuangan untuk setiap desa dan kelurahan. Alokasi dana Program P2DK untuk setiap desa/kelurahan adalah sebesar Rp. 200.000.000 (Dua Ratus Juta Rupiah)-5\% atau Rp. 10.000 .000 (kebutuhan operasional) = Rp.190.000.000 untuk melaksanakan kegiatan.

Jenis kegiatan program di desa lebih diprioritaskan pada kegiatan pertanian, perkebunan, peternakan, perikanan dan kegiatan ekonomi lain yang bermanfaat/ usaha mikro kecil dan menengah, sedangkan jenis-jenis kegiatan untuk di kelurahan lebih diprioritaskan untuk pemberdayaan ekonomi masyarakat seperti pemberian bantuan gerobak dan tenda dagangan dan lainnya.

Berdasarkan hasil penelitian dapat diketahui implementasi Program Percepatan Pembangunan Desa/Kelurahan di Kabupaten Sarolangun Provinsi Jambi sudah dilakukan berdasarkan prosedur dan petunjuk yang telah ditentukan oleh pemerintah. Namun dalam proses pelaksanaannya masih belum optimal. Masih terdapat beberapa kendala yang menjadi penghambat proses implementasi kebijakan. Kendala tersebut merupakan kendala yang mendasar, diantaranya mengenai SDM, Karakteristik Agen Pelaksana, dan proses pola komunikasi yang dilakukan oleh implementor kebijakan (Purwanto, 2012).

Oleh sebab itu kendala-kendala tersebut di analisis penyebabnya berdasarkan teori model implementasi kebijakan George C. Edwards III. Model implementasi kebijakan ini memberikan pandangan bahwa implementasi kebijakan dipengaruhi oleh empat variabel, yakni komunikasi, sumber daya, disposisi (sikap), dan struktur birokrasi. 


\section{Aspek Komunikasi}

Komunikasi merupakan salah satu faktor yang mempengaruhi implementasi kebijakan, Penyaluran komunikasi dilakukan secara langsung dari pelaksana kebijakan (implementor) ke kelompok sasaran yaitu masyarakat (kelompok tani) yang ada di Kabupaten Sarolangun.

Hasil penelitian tentang Komunikasi yang terjadi dalam implementasi kebijakan Program P2DK di Kabupaten Sarolangun sebagian sudah dilaksanakan dengan baik, namun masih ditemukan kekurangan, dikarenakan penyampaian informasi pada tingkat desa/kelurahan belum dilakukan secara intens. Penyampaian informasi juga ada yang kurang jelas, dikarenakan kemampuan implementor dalam menangkap dan memahami informasi yang disampaikan juga berbeda.

Berdasarkan hasil wawancara dengan beberapa informan mengenai komunikasi menunjukkan bahwa mekanisme penyampaian informasi maupun petunjuk pelaksanaan Kebijakan Program P2DK sudah dilaksanakan secara konsisten serta dilakukan sesuai peraturan yang berlaku oleh Dinas PMD terhadap Desa dan Kelurahan, serta selalu mengawasi dan mengarahkan agar proses dalam implementasi sesuai dengan peraturan dan petunjuk pelaksanaan. Namun berbeda dengan hasil wawancara dengan informan lainnya, yang menyebutkan :

"Penyampaian informasi tentang P2DK hanya dilakukan pada saat musrembang desa saja yakni dilaksanakan satu kali dalam satu tahun, jadi kami tidak tahu tentang perkembangan dan keberhasilan yang sudah dicapai oleh desa dalam melaksanakan tugasnya" (wawancara pada tanggal 20 April 2019).

Hasil wawancara lainnya menyatakan bahwa:

"Terus terang saja, kami selaku warga desa, tidak tahu banyak mengenai Program P2DK, karena tidak pernah mendapat sosialisasi mengenai program, apalagi mendapat bantuannya”. (wawancara tanggal 15 April 2019).

Dari beberapa kutipan wawancara diatas dapat diketahui bahwa komunikasi yang dilakukan pada tingkat desa/kelurahan kepada masyarakat belum dilaksanakan secara intens dan masih ada masyarakat yang belum mengetahui adanya Program P2DK.

\section{Aspek Sumber Daya}

Faktor Sumber Daya manusia berperan penting dalam implementasi kebijakan publik. Perintah-perintah implementasi mungkin diteruskan secara cermat, jelas dan konsisten, tetapi jika para pelaksana kekurangan sumber-sumber yang diperlukan untuk melaksanakan kebijakan maka implementasi cenderung tidak efektif (Nugroho, 2014).

Dengan triangulasi teknik pengumpulan data, peneliti melakukan kroscek data hasil wawancara, telaah dokumentasi dan pengamatan di lapangan. Dari data yang di peroleh peneliti dapat menjelaskan bahwa aspek Sumber Daya, dapat diketahui bahwa indikator staf, informasi, wewenang, dan fasilitas : Pertama, Staf di Bidang UEM \& TTG pada seksi Usaha Ekonmi Masyarakat hanya berjumlah 2 (dua) orang staf, sehingga program dan kegiatan dalam implementasi kebijakan tidak berjalan efektif. Staf pendamping Program P2DK juga perlu dikaji kembali apakah harus ada penambahan atau 
perombakan. Kedua, pimpinan sudah menginformasikan kepada pelaksana berupa petunjuk dan arahan untuk melaksanakan kebijakan dan bagaimana harus melakukan Program P2DK. Desa dan Kelurahan menindaklanjuti dan memberikan informasi kepada masyarakat (target group) agar memahami petunjuk teknis yang sudah diinformasikan, namun informasi diberikan tidak diberikan kepada masyarakat luas dan kurangnya asas transparansi dan akuntabilitas terhadap masyarakat. Ketiga, Kepala Dinas sudah memberikan mandat kepada pihak ketiga (pendamping Program P2DK) untuk mengawasi pelaksanaan implementasi Kebijakan di Kabupaten Sarolangun. Namun pelaksanaannya terkendala beberapa faktor, yaitu luas wilayah tidak sebanding dengan jumlah pendamping yang ada sehingga pelaksanaan wewenang tidak berjalan dengan efektif. Keempat, bahwa fasilitas fisik berupa alat tulis kantor, kendaraan operasioanl dinas untuk melakukan koordinasi dirasa belum memadai.

\section{Aspek Disposisi}

Menurut (Wahab Ahmad, 2010) mengemukakan "kecenderungan-kecenderungan atau disposisi merupakan salah-satu faktor yang mempunyai konsekuensi penting bagi implementasi kebijakan yang efektif". Jika para pelaksana mempunyai kecenderungan atau sikap positif atau adanya dukungan terhadap implementasi kebijakan maka terdapat kemungkinan yang besar implementasi kebijakan akan terlaksana sesuai dengan keputusan awal. Demikian sebaliknya, jika para pelaksana bersikap negatif atau menolak terhadap implementasi kebijakan karena konflik kepentingan maka implementasi kebijakan akan menghadapi kendala yang serius.

Dengan triangulasi teknik pengumpulan data, peneliti melakukan kroscek data hasil wawancara, telaah dokumentasi dan pengamatan di lapangan, untuk itu dapat dijelaskan bahwa aspek Disposisi, diketahui bahwa: Pertama, Pengangkatan Birokrat sudah cukup baik dan dedikasi dari pelaksana kebijakan sudah cukup baik dari segi administratif namun perlu dilakukan evaluasi agar penyelenggaran Program P2DK menjadi lebih optimal. Kedua, pelaksanaan implementasi kebijakan Program P2DK sangat direspon dan didukung oleh pelaksana. Namun dalam implementasi belum ditunjang dengan reward dan punishment terhadap pelaksana kebijakan sehingga tidak ada dorongan untuk melakukan inovasi yang berdampak pada kesuksesan Program P2DK di Kabupaten Sarolangun.

\section{Aspek Struktur Birokrasi}

Kemudian aspek selanjutnya yang menjadi tolak ukur keberhasilan implementasi kebijakan Program P2DK yaitu memerlukan dukungan Birokrasi yang merupakan salah satu institusi yang secara keseluruhan menjadi pelaksana kegiatan. organisasi. Kebijakan yang begitu kompleks perlu adanya kerjasama dengan banyak orang. Ketika struktur birokrasi tidak kondusif maka akan menghambat implementasi kebijakan.

Berdasarkan hasil wawancara terkait dengan struktur birokrasi dapat kita ketahui bahwa: Pertama, Standart Operating Procedure (SOP) sudah tersedia di Dinas PMD Sarolangun, untuk pelaksanaan Kebijakan yang selama ini dilaksanakan juga mengacu 
pada Peraturan Daerah Nomor 39 Tahun 2018 tentang petunjuk teknis pelaksanaan. Kedua, Fragmentasi atau penyebaran tanggung jawab berupa koordinasi dengan organisasi perangkat daerah terkait melalui program P2DK juga belum dilaksanakan secara berkelanjutan dan tersruktur karena fragmentasi belum berjalan dengan baik, sehingga pelaksaan kebijakan menjadi belum optimal.

\section{Kesimpulan}

Berdasarkan pembahasan hasil penelitian penulis berusaha mempresentasikan mengenai Implementasi Program Percepatan Pembangunan Desa/Kelurahan di Kabupaten Sarolangun, dengan mengemukakan kesimpulan bahwa kinerja pelaksanaan Program P2DK masih belum optimal dalam mengurangi angka kemiskinan yang disebabkan oleh beberapa aspek implementasi kebijakan, diantaranya yaitu :

Dengan menggunakan 4 faktor analisis menurut teori model implementasi Edward III diantaranya : (a). Faktor Komunikasi dalam lingkup internal Dinas PMD sudah berjalan dengan baik. Namun komunikasi eksternal antara Dinas PMD dengan Stakeholder lain dan kelompok masyarakat intensitasnya masih rendah. Sehingga diperlukan upaya lain dalam meningkatkan intensitas sosialisasi. (b). Faktor Sumber Daya pada Dinas PMD masih sangat terbatas, jumlah staf yang ada di Bidang UEM \& TTG dalam melaksanakan monitoring masih kurang, serta kompetensi berdasarkan kualifikasi pendidikan pada pelaksana dan pendamping program juga kurang memadai. Sehingga diperlukan upaya lain dalam mengontrol dan mendampingi masyarakat dalam melaksanakan kegiatan program. (c). Faktor Disposisi, sikap dari para pelaksana adalah mendukung pelaksanaan kebijakan program P2DK, hanya saja sejauh ini para implementor program menganggap bahwa Program P2DK tidak ada bedanya dengan proyek-proyek pengentasan kemiskinan terdahulu yang sekedar memberikan bantuan dana saja, sehingga diperlukan upaya untuk meningkatkan insentif pelaksana dengan adanya sistem reward dan punishment yang diberikan oleh Dinas PMD bagi para pelaksananya. (d). Selanjutnya Struktur Birokrasi pada pelaksanaan Program P2DK di Kabupaten Sarolangun masih dilaksanakan oleh single actor saja hal ini disebabkan rendahnya koordinasi antar organisasi, sehingga diperlukan upaya untuk menyatukan stakeholder dalam unit khusus kelembagaan untuk menangani kegiatan teknis dalam pelaksanaan Program P2DK.

Memberikan reward dan punishment untuk Kepala Desa dan Lurah berupa tambahan dan pengurangan anggaran bagi yang dinilai berhasil dan tidak berhasil dalam melaksanakan program (d) Memperbaiki sistem kelembagaan pelaksanaan Program Percepatan Pembangunan Desa dan kelurahan (P2DK). 
Model Optimalisasi Pelaksanaan Program Percepatan Pembangunan Desa/Kelurahan (P2DK) di Kabupaten Sarolangun

\section{Bibliografi}

Agustino, L. (2014). Dasar-dasar kebijakan publik (VI). Bandung: Alfabeta.

Arifiyanto, D. F., \& Kurrohman, T. (2014). Akuntabilitas pengelolaan alokasi dana desa di Kabupaten Jember. Jurnal Riset Akuntansi Dan Keuangan, 2(3), 473-485.

BPS Provinsi Jambi. (2018). BPS Provinsi Jambi.

Nugroho, R. (2014). Kebijakan publik di negara-negara berkembang. Yogyakarta: Pustaka Pelajar.

Purwanto, E. A. (2012). Implementasi Kebijakan Publik Konsep dan Aplikasinya di Indonesia (Issue 1). 2012.

Sarolangun, R. K. (2018). RPJMD Kabupaten Sarolangun.

Wahab Ahmad. (2010). Politik Hukum Pidana Dalam Perspektif Penegakan Hukum Tindak Pidana Korupsi Di Indonesia. UMI.

Wahab, S. A. (2012). Analisis kebijakan: dari formulasi ke penyusunan model-model implementasi kebijakan publik. Jakarta: Bumi Aksara, 77.

Yusria, K., Komariah, K., \& Kadarisman, A. (2019). TRANSFORMASI IDENTITAS ANGGOTA GERAKAN PEMUDA HIJRAH (Studi Fenomenologi tentang Perubahan Pola Komunikasi dan Citra Diri Anggota Gerakan Pemuda Hijrah). JRK (Jurnal Riset Komunikasi), 9(1). 